\title{
Additive Effects of Water-Soluble Propolis (Greit 120) and Human Interferon Alfa (HuIFN- $\alpha$ N3) against Influenza Viruses in Vitro
}

\author{
Bratko Filipič ${ }^{1}$, Lidija Gradišnik ${ }^{2}$, Adriana Pereyra ${ }^{3}$, Rok Kopinč ${ }^{3}$, Klemen Rihar ${ }^{4}$, Eva Ružić-Sabljić ${ }^{5}$, \\ Snežana Kramar ${ }^{5}$, Damir Đermić ${ }^{1,6}$, Eugen Šoos ${ }^{* 7}$, Nicola Volpi ${ }^{8}$, Alfredo Fachinii ${ }^{9}$ and Hrvoje Mazija ${ }^{1}$ \\ 1. Croatian Institute of Experimental and Translation Oncology, Koledinećka 3, Zagreb 10040, Croatia \\ 2. Institute of Biomedical Sciences, Medical Faculty of Maribor, Taborska 8, Maribor 2000, Slovenia \\ 3. Medex D.o.o., Linhartova 49b, Ljubljana 1000, Slovenia \\ 4. Chengdujska 4, Ljubljana 1000, Slovenia \\ 5. Institute of Microbiology and Immunology, Medical Faculty, Zaloška 4, Ljubljana 1105, Slovenia \\ 6. Division of Molecular Biology, Ruđer Bošković Institute, Bijenička 54, Zagreb 10000, Croatia \\ 7. Trg Sv. Ivana 5, Kloštar Ivanić 10312, Croatia \\ 8. Department of Life Sciences, University of Modena \& Reggio Emilia, Modena 41125, Italy \\ 9. BNatural, Via Gran Sasso 33, Corbetta-MI 20011, Italy
}

\begin{abstract}
Influenza virus affects the respiratory tract in humans causing a range of distinct manifestations including fever, nasal secretions, cough, headaches, muscle pain and pneumonia, which could become violent and severe. It was found that influenza A viruses remain resistant to amantadine and rimantadin with high level of oseltamvir resistance. Therefore, there is a need for constant improvement of drugs active against resistant influenza viruses. Propolis has anti-influenza activity both in vitro and in vivo. Human leukocyte interferon (HuIFN- $\alpha \mathrm{N} 3)$ is a multi-subtype protein that displays an antiviral activity against influenza virus. In this study we elucidated the anti-influenza activity of the mixes of water-soluble propolis (WSP) (Greit 120) and HuIFN- $\alpha \mathrm{N} 3$ at different ratios. Greit 120 polyphenols, total phenol acids and bioflavonoid were characterized by HPLC-UV-ESI-MS504971 and HuIFN- $\alpha$ N3 by reverse-phase high-performance liquid chromatography (RP-HPLC). Influenza A and B viruses were separately added to the LLC-MK2 cells treated with WSP (Greit 120) and HuIFN- $\alpha$ N3 alone or in proportions 1:1, 1:2 and 2:1. Plates were incubated and cytopathic effect was determined. The best results $\left(\mathrm{ID}_{50}\right)$ were obtained with the mix of $10 \%$ WSP and HuIFN- $\alpha \mathrm{N} 3$ in proportion $1: 2$, showing $\mathrm{ID}_{50}$ at $12 \pm 0.2 \mu \mathrm{g} / \mathrm{mL}$ and $19 \pm 0.6 \mu \mathrm{g} / \mathrm{mL}$ for influenza A and B viruses, respectively. When comparing anti-influenza activity of WSP (Greit 120)/HuIFN- $\alpha$ N3 with that of ribavirin, it was found that 1:2 was the optimal ratio for WSP (Greit 120)/HuIFN- $\alpha$ N3 (0.5 and 0.6 for influenza A and B, respectively). This new formulation of WSP (Greit 120) and HuIFN- $\alpha$ N3, showing better anti-Influenza activity, will definitely improve its application in flu infections.
\end{abstract}

Key words: Water-soluble propolis, Greit 120, HuIFN- $\alpha$ N3, anti-influenza activity, ribavirin, $\mathrm{ID}_{50}$.

\section{Introduction}

Influenza virus affects the respiratory tract in humans and animals leading to a range of diverse symptoms, consisting of fever, nasal secretions, cough,

Corresponding author: Bratko Filipič, Ph.D., research fields: apidology, imunology, virology and microbiology.

* Paper is devoted to the remembrance of Dr. Eugen Šooš, who passed away in December 2017. headache, muscle pain and pneumonia which usually could become severe $[1,2]$. During influenza season, antigenic drift in the virus usually appears when the design of the year's vaccine was then established. Therefore, the vaccine became less protective and outbreaks occur [3]. The pandemic avian H5N1 and $\mathrm{H} 1 \mathrm{~N} 1$ and then changed influenza virus A (H3N2) strains have expanded worldwide, so the emergence of 
pathogenic influenza virus strains can be anticipated [4].

It is noticed that most influenza A viruses remained resistant to amantadine and rimantadine with a high degree of oseltamivir resistance (but zanamivir sensitivity) in the seasonal wave of infection with H1N1 [5]. Therefore, a constant improvement of new anti-influenza virus drugs active against resistant influenza viruses is constantly required.

As a folk medicine since $300 \mathrm{BC}$, bee propolis is used as a food supplement for maintenance or improvement of human health [6]. It is composed of resins (40\%-55\%), beeswax and fatty acids (20\%-35\%), essential oils (10\%), pollen (5\%) and other ingredients, such as minerals, vitamins and sugar. The chemical arrangement of propolis is complex and in it, over 180 compounds were determined. Among them, the polyphenols are most significant [7]. Its chemical composition differs, depending on origin and local plant ecology. Propolis' pharmacological properties were accounted as anti-carcinogenic [8], anti-inflammatory [9] and anti-microbial [10]. The antiviral activity against several viruses [11] was further shown, e.g., adenovirus [12], HIV [13], herpes simplex virus $[14,15]$ and anti-influenza activity [16, 17] both in vitro and in vivo.

Human leukocyte interferon (HuIFN- $\alpha$ N3) is a multi-subtype protein showing antiviral, anti-proliferative, anti-tumor, radio-protective and anti-toxic activity. There are three main classes of IFNs, designated as Types I, II and III [18]. Type I includes IFN- $\alpha$, IFN- $\beta$, IFN- $\delta$, IFN- $\varepsilon$, IFN- $\zeta$, IFN- $\kappa$, IFN- $-v$, IFN- $\tau$, and IFN- $\omega$. Type II is composed of a single cytokine, IFN- $\gamma$ [19]. Types III is IFN- $\lambda 1$, IFN- $\lambda 2$, IFN- $\lambda 3$ and IFN- $\lambda 4$. Type I- and type III-IFNs with similar signal transduction systems stay linked to each other than type II-IFN [20]. It is applied to treat a variety of viral illnesses and cancers. Among viruses, there are influenza A and B being susceptible to low dosage of HuIFN- $\alpha \mathrm{N} 3$ [21-23]. It is crucial to analyze the effectiveness of the combo of extract of propolis (EEP) and water-soluble propolis (WSP) (Greit 120) with HuIFN- $\alpha \mathrm{N} 3$ and through this to improve their potential clinical usefulness.

The purpose of the performed experiments was to elucidate the anti-influenza activity against influenza viruses $\mathrm{A}$ and $\mathrm{B}$, of the combos of WSP (Greit 120) and $\mathrm{HuIFN}-\alpha \mathrm{N} 3$ in vitro.

\section{Materials and Methods}

\subsection{Cells and Viruses}

LLC-MK2 cells were cultivated in the Eagle's medium with $10 \%$ fetal calf serum (FCS) and antibiotics. Influenza A and B viruses' different clinical isolates were from Virological Department of the Institute of Microbiology and Immunology of the Medical Faculty in Ljubljana (Slovenia).

\subsection{Compounds Employed in the Experiments}

The 10\% WSP prepared from 30\% WSP (Greit 120) was obtained from BNatural, Corbetta (Italy). And 10\% EEP was from Medex D.o.o., Ljubljana (Slovenia). HuIFN- $\alpha \mathrm{N} 3$ was from Institute of Immunology, Zagreb (Croatia).

\subsection{Inhibition of Influenza A and B Viruses Evaluated} with Plaque Reduction Assays

Approximately $6 \times 10^{3}$ LLC-MK2 cells/well in Eagle's medium $+10 \%$ FCS were seeded into 96-well plates, and incubated for $24 \mathrm{~h}$ at $37{ }^{\circ} \mathrm{C}$ in $5 \% \mathrm{CO}_{2}$ atmosphere. After reaching the confluence, the Eagle's medium $+10 \%$ FCS were removed and on each plate from second to eleventh well were added $100 \mu \mathrm{L}$ of Eagle's medium $+2 \%$ FCS. In the first well $200 \mu \mathrm{L}$ of: $10 \%$ EEP, $10 \%$ EEP + HuIFN- $\alpha$ N3 (1:1, 1:2 and 2:1), 10\% WSP (Greit 120), 10\% WSP (Greit 120) $+\mathrm{HuIFN}-\alpha \mathrm{N} 3(1: 1,1: 2$ and $2: 1), 200 \mu \mathrm{L}$ of HuIFN- $\alpha \mathrm{N} 3$ and $200 \mu \mathrm{L}$ of ribavirin as a control. All samples were serially diluted and incubated for $8 \mathrm{~h}$ at $37^{\circ} \mathrm{C}$. Samples were added in two parallels and three replicates. Then, medium with samples was removed and influenza A and separately influenza B viruses 
(100 $\mu \mathrm{L} /$ well) were added and plates incubated at $37{ }^{\circ} \mathrm{C}$ for $24 \mathrm{~h}$ in $5 \% \mathrm{CO}_{2}$ atmosphere, when in the control $100 \%$ cytopathic effect (CPE) with small plaques were established. The plates with treated/infected LLC-MK2 cells were rinsed with phosphate-buffered saline (PBS), fixed with 5\% glutaraldehyde, washed further with PBS and to them $100 \mu \mathrm{L}$ of crystal violet was added for twenty minutes. With PBS, washed plates were air-dried and measured at $570 \mathrm{~nm}$. The effective concentrations for $\mathrm{ID}_{50}$ were determined from a curve relating the plaque number to the concentrations of the propolis extracts and HuIFN- $\alpha$ N3 [24, 25]. Effect of various combinations of EEP or WSP (Greit 120) with HuIFN- $\alpha \mathrm{N} 3$ in different combinations (1:1, 1:2 and 2:1) on influenza $\mathrm{A}$ and $\mathrm{B}$ viruses was further expressed as a ratio to ribavirin [26] by Eq. (1):

$$
\text { Ribavirin } \mathrm{ID}_{50} \text { index }=\frac{\begin{array}{c}
\text { Propolis' extract and/or } \\
\text { HuIFN- } \alpha \mathrm{N} 3(1: 1,1: 2,2: 1) \mathrm{ID}_{50}
\end{array}}{\text { Ribavirin } \mathrm{ID}_{50}}
$$

\subsection{Analysis of HuIFN- $\alpha$ N3 by RP-HPLC}

The HuIFN- $\alpha$ N3 subtype composition was analyzed by reverse-phase high-performance liquid chromatography (RP-HPLC). Used HPLC column was Phenomenex, Aeris ${ }^{\mathrm{TM}}$ Peptide column $3.6 \mu \mathrm{m}$ XB-C18, $250 \times 4.6 \mathrm{~mm}$. On it, different HuIFN- $\alpha$ samples (natural and recombinant) by approximately one million of antiviral units $(\mathrm{AU} / \mathrm{mL})$ in a volume of $20-40$ $\mu \mathrm{L}$ were put on the column. Adsorbed, were eluted by the linear gradient of solvent A (distilled water $+0.1 \%$ of trifluoroacetic acid (TFA)) and solvent $\mathrm{C}$ (acetonitrile $+0.1 \%$ TFA) for 20 min with a flow rate of $0.8 \mathrm{~mL} / \mathrm{min}$ and pressure of $139-140$ bars. The courses of RP-HPLC chromatography of different
HuIFN- $\alpha$ N3 samples are shown in Table 1 . Temperature of the column was $40^{\circ} \mathrm{C}$. The absorbance was measured at $214 \mathrm{~nm}$ and $280 \mathrm{~nm}$. HuIFN- $\alpha \mathrm{N} 3$ species of different compositions separated agreeing to the fact that there is relative hydrophobic pattern using RP-HPLC [27, 28].

\subsection{The Detection of Pinocembrin and Galangin by RP-HPLC Method}

In $10 \mathrm{~mL}$ burette, $1.0 \mathrm{mg}$ of pinocembrin or galangin were put and diluted to $10.0 \mathrm{~mL}$ with methanol. From this solution, $150 \mu \mathrm{L}$ of the samples were transferred into a vial and loaded with $1.350 \mu \mathrm{L}$ of methanol. Samples filtered through a $0.45 \mu \mathrm{m}$ filter were injected by $20 \mu \mathrm{L}$ into the HPLC column. In the experiments HPLC column Purospher ${ }^{\circledR}$ STAR RP-18 $5 \mu \mathrm{m}, 150 \times 4.6 \mathrm{~mm}$ was used. The conditions of the HPLC procedure: (a) temperature of the column: $25^{\circ} \mathrm{C}$; (b) flow: $0.7 \mathrm{~mL} / \mathrm{min}$; (c) pressure: $90-100$ Bar; (d) ate: 62.5 ; (e) absorbance: $290 \mathrm{~nm}$; (f) injection volume: $20 \mu \mathrm{L}$; (g) gradient: solvent A (distilled water $+1 \%$ formic acid), solvent $C$ (acetonitrile) [29]. Steps of various HPLC runs are presented in Table 2.

\subsection{Statistical Analysis}

The $\mathrm{ID}_{50}$ based on the mean plaque number was calculated on the raw data of an in-triplicate assay by regression analysis using Probit (SPSS statistical software package), determining the concentration of drug required to reduce the number of plaques by $50 \%$. Statistical analysis of the experimental data was performed with a two-tailed Student's $t$-test for paired samples with a $p=0.05$ as the smallest level of significance.

Table 1 Time course of RP-HPLC chromatography of different HuIFN- $\alpha$ N3 samples.

\begin{tabular}{llll}
\hline Step: chromatography of different IFN samples in step & Time (min) & Solvent A (\%) & Solvent C (\%) \\
\hline 0 & 0 & 91 & 9 \\
1 & 3 & 80 & 20 \\
2 & 6 & 50 & 50 \\
3 & 12 & 50 & 50 \\
4 & 15 & 91 & 9 \\
5 & 20 & 91 & 9 \\
\hline
\end{tabular}


Table 2 The steps of the RP-HPLC detection of pinocembrin and galangin.

\begin{tabular}{llll}
\hline Step: Chromatography of pinocembrin and galangin step & Time (min) & Solvent A (\%) & Solvent C (\%) \\
\hline 0 & 0 & 70 & 30 \\
1 & 5 & 60 & 40 \\
2 & 15 & 60 & 40 \\
3 & 20 & 35 & 65 \\
4 & 25 & 35 & 65 \\
5 & 30 & 70 & 30 \\
6 & 35 & 70 & 30 \\
\hline
\end{tabular}

\section{Results}

\subsection{RP-HPLC Analyses of Sendai Virus (Cantell Strain)

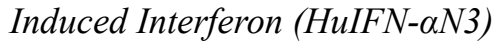

HuIFN- $\alpha$ N3 subtypes in different samples (natural or recombinant) are separated according to its relative hydrophobicity using HPLC column Purospher ${ }^{\circledR}$ STAR RP-18 $5 \mu \mathrm{m}$. The separation of different HuIFN- $\alpha \mathrm{N} 3$ subtypes in the samples was achieved by increasing acetonitrile concentration [29, 30]. The least hydrophobic interferon subtypes were eluted as early peaks and the most hydrophobic Interferon subtypes eluted as later. As standards, different human recombinant interferons $\alpha$ was used: HuIFN- $\alpha$ A, HuIFN- $\alpha 2 a$ and HuIFN- $\alpha 2 b$. Their chromatograms and the chromatograms at $280 \mathrm{~nm}$ of the Russian HuIFN- $\alpha \mathrm{N} 3$ (NDV induced) and $\mathrm{HuIFN}-\alpha \mathrm{N} 3$ of Institute of Immunology Zagreb (Croatia) were used as standards (Fig. 1A). The positions of different HuIFN- $\alpha \mathrm{N} 3$ subtypes were determined according to the $214 \mathrm{~nm}$ chromatogram in comparison to the protein profile measured at $280 \mathrm{~nm}$. The predominant components of the Sendai virus induced HuIFN- $\alpha \mathrm{N} 3$, are shown in Fig. 1B, and are natural IFN subtypes: $\alpha 1, \alpha 2, \alpha \mathrm{A}, \alpha 2 \mathrm{~b}$ and $\alpha 14$. The most important is the relative ratio between $\alpha 1$ and $\alpha 2$ (values of mAU relative units) [30]. Various types of HuIFN- $\alpha \mathrm{N} 3$ inductors differ in induction capacity of IFN subtypes: $\alpha 1, \alpha 2, \alpha \mathrm{A}, \alpha 2 \mathrm{~b}$ and $\alpha 14$. The HuIFN- $\alpha \mathrm{N} 3$ subtype's antiviral activity in $\mathrm{IU} / \mathrm{mL}$ was determined by the detection of their antiviral activity according to the standard procedure: Monolayer received interferon dilution at two-fold increasing levels overnight. The following morning, the medium was removed and $100 \mu \mathrm{L}$ of challenge virus (vesicular stomatitis virus) in Eagle's medium $+2 \%$ FCS were added, and the cell layers were examined in a microscope $24 \mathrm{~h}$ later and scored $(+4,+3,+2,+1,+0$ corresponding to $100 \%$ destruction, $75 \%, 50 \%, 25 \%$, non-infected, respectively) [31] (Table 3).

\subsection{Quantity of Caffeic Acid, Crysin, Pinocembrin and Galangin in $10 \%$ EEP}

The $1.0 \mathrm{mg}$ of caffeic acid, crysin, pinocembrin and galangin were put and diluted to $10.0 \mathrm{~mL}$ with methanol. From this solution, $150 \mu \mathrm{L}$ of the sample was transferred into a vial and loaded with $1.350 \mu \mathrm{L}$ of methanol. Samples filtered through a $0.45 \mu \mathrm{m}$ filter were injected by $20 \mu \mathrm{L}$ into the HPLC column Purospher ${ }^{\circledR}$ STAR RP-18 $5 \mu \mathrm{m}$. Their separation was achieved with acetonitrile gradient in HPLC column (Fig. 2A). The 10\% EEP was analyzed under the same conditions in the Purospher ${ }^{\circledR}$ STAR RP-18 $5 \mu \mathrm{m}$ HPLC column. Its separation measured at $290 \mathrm{~nm}$, with acetonitrile gradient is presented in Fig. 2B [32]. The quantity of caffeic acid, crysin, pinocembrin and galangin in the experimental sample of $10 \%$ EEP was calculated in comparison to standards (Fig. 2A). Therefore, Table 4 indicates the quantity of caffeic acid, crysin, pinocembrin and galangin in the $10 \%$ EEP.

3.3 Molecular Composition of WSP (Greit 120) Determined by HPLC-UV-ESI-MS 504971

Fig. 3 shows the HPLC-UV-ESI-MS504971 profile of WSP (Greit 120). 


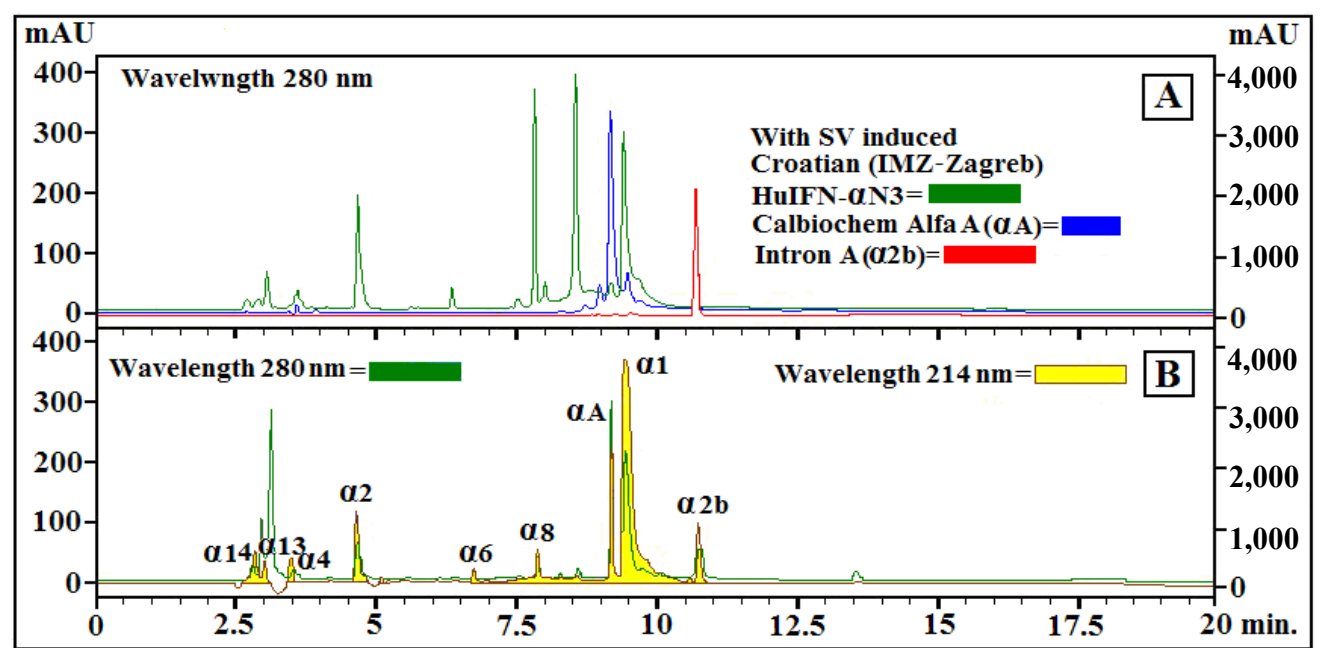

Fig. 1 RP-HPLC profiles of the Sendai virus-induced HuIFN- $\alpha$ N3.

(A) SV = Sendai virus (Cantell strain). Protein profiles of the various IFNs at $280 \mathrm{~nm}$; (B) protein profile at $280 \mathrm{~nm}$ ( $)$ and IFN profile at $214 \mathrm{~nm}$ (־) of HuIFN- $\alpha$ N3 induced with $100 \mathrm{HA} / \mathrm{mL}$ of Sendai virus (Cantell strain).

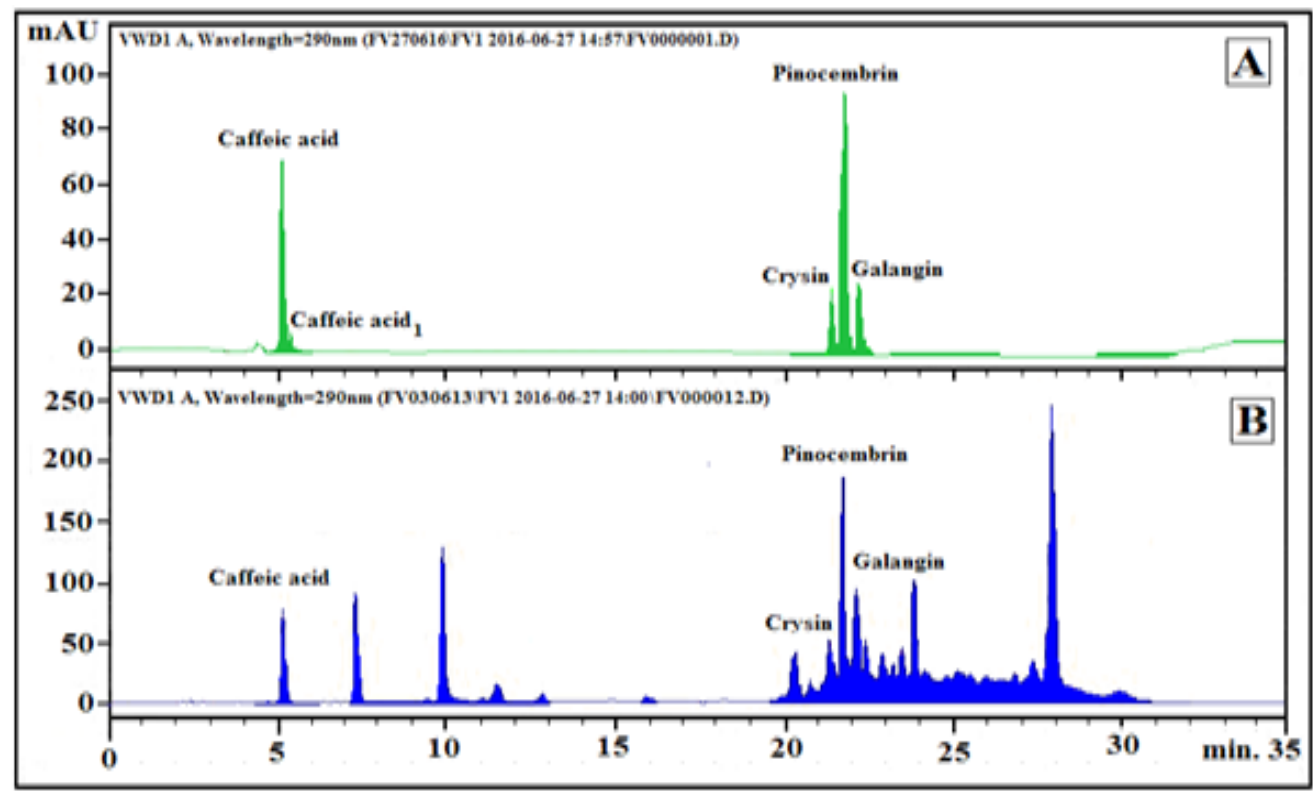

Fig. 2 RP-HPLC profile of the bio-flavonoid's standards (caffeic acid, crysin, pinocembrin and galangin) (A); the RP-HPLC profile of 10\% EEP (Medex d.o.o., 1000 Ljubljana, Slovenia) (B).

Table 3 The subtype composition of the Sendai virus (Cantell strain) induced HuIFN- $\alpha$ N3.

\begin{tabular}{lll}
\hline No. & HuIFN- $\alpha$ N3 subtype & $\mathrm{IU} / \mathrm{mL}$ \\
\hline 1 & $\alpha \mathrm{A}$ & 22.430 \\
2 & $\alpha 2 \mathrm{~b}$ & 11.000 \\
3 & $\alpha 1$ & 44.280 \\
4 & $\alpha 2$ & 11.750 \\
5 & $\alpha 6$ & 1.280 \\
6 & $\alpha 8$ & 1.800 \\
7 & $\alpha 13$ & 1.800 \\
8 & $\alpha 14$ & 3.500 \\
& Complete HuIFN- $\alpha \mathrm{N} 3$ & 100.000 \\
\hline
\end{tabular}


Table 4 Quantity of caffeic acid, crysin, pinocembrin and galangin in $10 \%$ EEP.

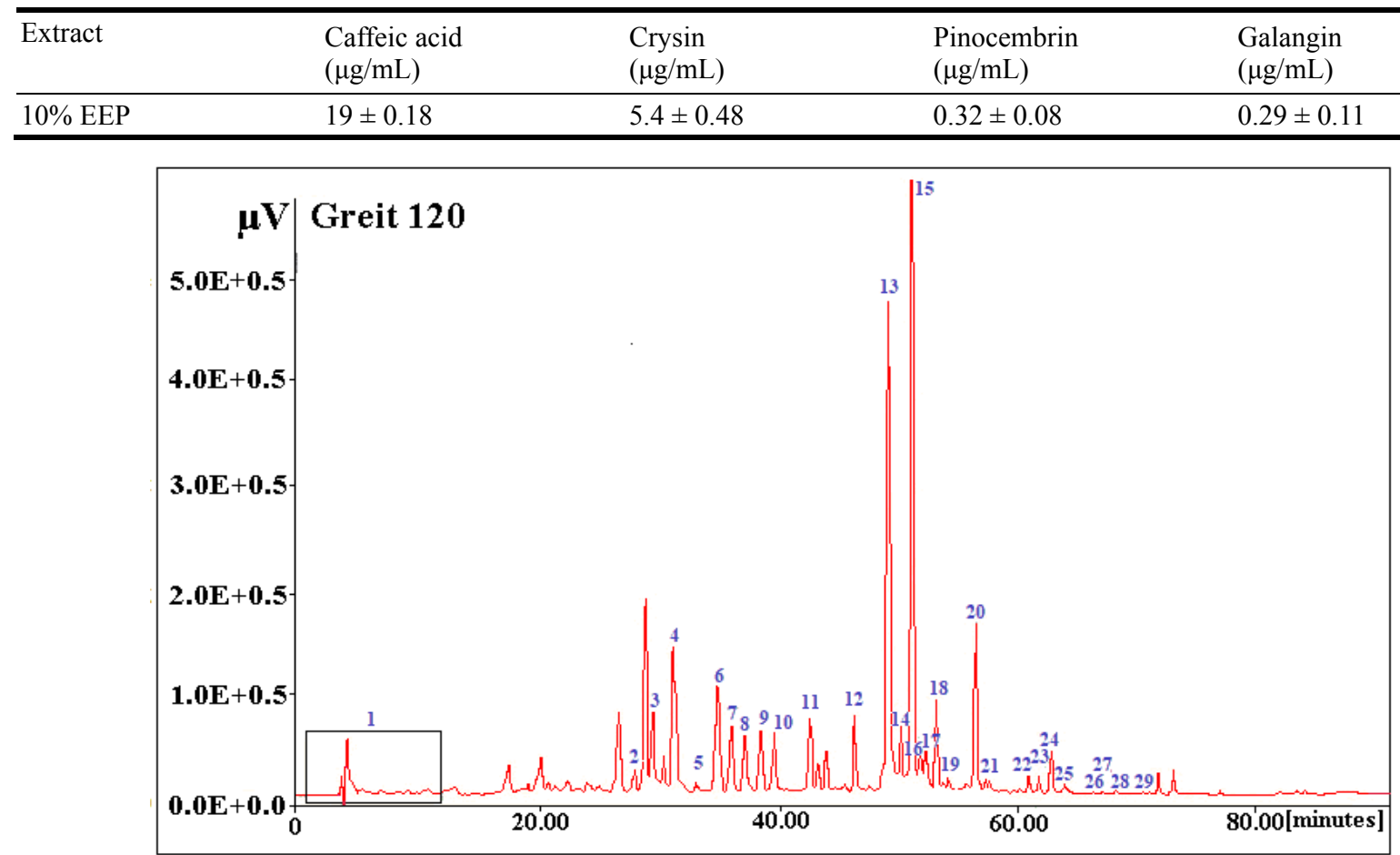

Fig. 3 HPLC-UV-ESI-MS504971 of flavonoid's profile of an average sample of WSP (Greit 120).

1 = phenolic acids (caffeic, coumaric, ferulic, isoferulic); 2 = quercetin; 3 = pinobanksin 5-methyl ester; 4 = quercetin 3-methyl ester; $5=$ pinobanksin; 6 = apigenin; $7=$ kaempferol; $8=$ isorhamnetin; $9=$ luteolin 5 -methyl ester; $10=$ quercetin 5-7-dimethyl ester; $11=$ galangin 5-methyl ester; 12 = quercetin 7-methyl ester; 13 = chrysin; 14 = pinocembrin; 15 = galangin; 16 = pinobanksin-3-O-acetate; 17 = CAPE; 18 = metoxychrysin; 19 = pinobanksin-3-O-propionate; 20 = caffeic acid cinnamyl ester; 21 = pinobanksin-3-O-butyrate; 22 = pinobanksyn-3-O-pentenoate; $23=$ other pinobanksin derivative; 24 = pinobanksin-3-O-hexanoate; $25=$ other pinobanksin derivative.

In Table 5, the molecular composition of WSP (Greit 120) in a very precise way is shown.

\subsection{Antiviral Activity of Combinations of $10 \%$ EEP, 10\% WSP (Greit 120) and HuIFN- $\alpha \mathrm{N3}$}

The experiments were performed to analyze the anti-influenza activity of 10\% WSP (Greit 120) and $10 \%$ EEP in combination with HuIFN- $\alpha \mathrm{N} 3$ in various proportions (1:1, 1:2 and 2:1). Ribavirin alone was a control. The results in Table 6 showed that the best results for $\mathrm{ID}_{50}$ were, when the combination of $10 \%$ WSP (Greit 120) and HuIFN- $\alpha$ N3 in ratio 1:2 was used $\left(\mathrm{ID}_{50} 12 \pm 2 \mu \mathrm{g} / \mathrm{mL}\right.$ for influenza $\mathrm{A}$ and $19 \pm 6$ $\mu \mathrm{g} / \mathrm{mL}$ for influenza B). With 10\% EEP and HuIFN- $\alpha$ N3, the best ratio was the same 1:2, where it was $22 \pm 7 \mu \mathrm{g} / \mathrm{mL}$ for influenza $\mathrm{A}$ and $15 \pm 4$ $\mu \mathrm{g} / \mathrm{mL}$ for influenza B (Table 7).

\subsection{Ribavirin $I D_{50}$ Index}

Ribavirin $\mathrm{ID}_{50}$ index was calculated to compare the $\mathrm{ID}_{50}$ (antiviral activity) of WSP (Greit 120) or 10\% EEP in combination with HuIFN- $\alpha \mathrm{N} 3$ in ratios $1: 1$, 1:2 and 2:1 in comparison to ribavirin. The results are in Tables 8 and 9 and Figs. 4 and 5. The lower is, the better it is. The ratio 1:2 was still the best with WSP (Greit 120) in combination with HuIFN- $\alpha$ N3 (0.5 for influenza $B$ and 0.6 for influenza A virus). With EEP in combination with HuIFN- $\alpha \mathrm{N} 3$, the best was the same ratio 1:2 (0.7 for influenza $B$ and 1.3 for influenza A virus). 
Table 5 The molecular composition of WSP (Greit 120) determined by HPLC-UV-ESI-MS504971.

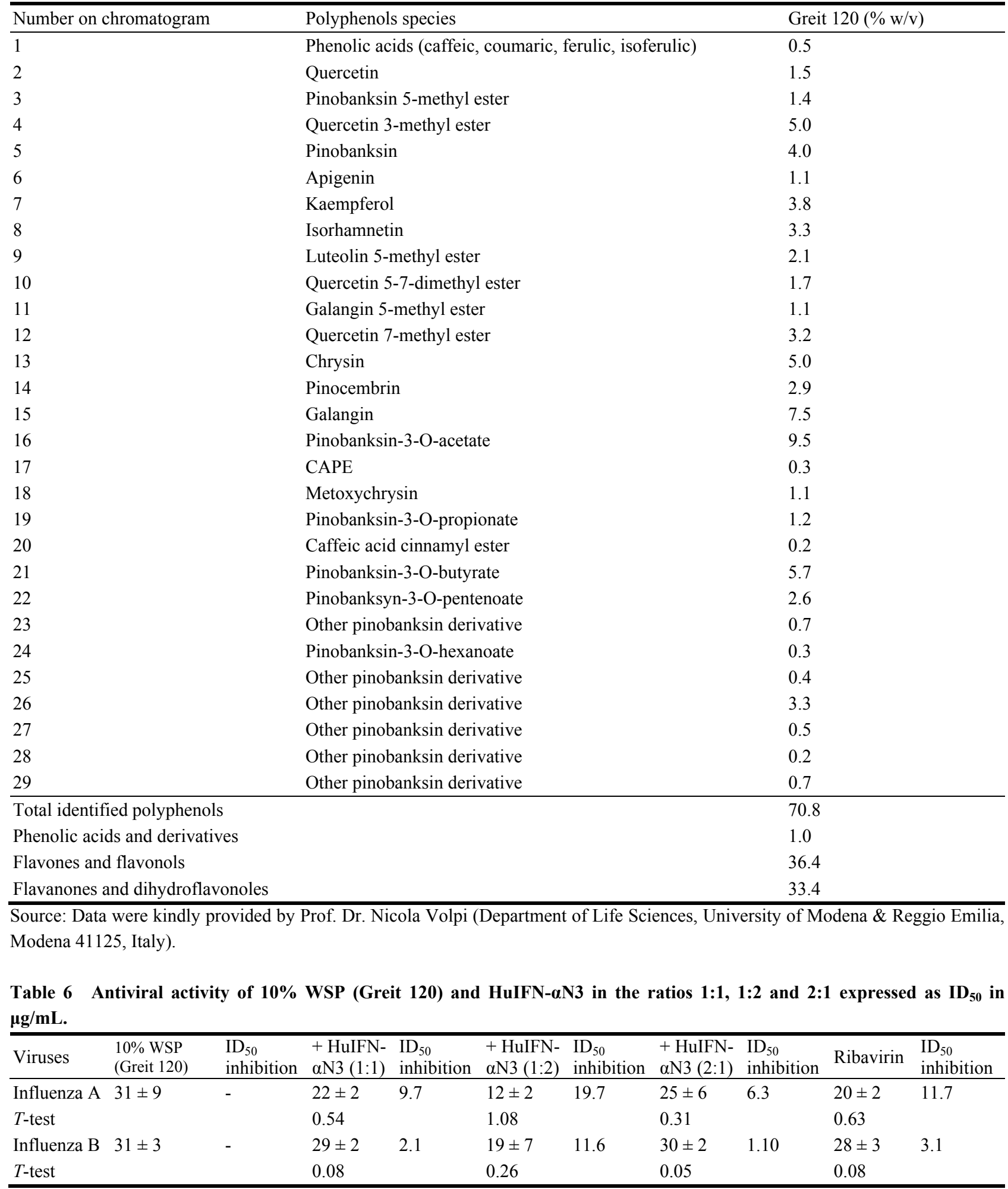

$\mathrm{ID}_{50}=$ Concentration of sample needed to reduce the virus-induced CPE to $50 \%$. 
Additive Effects of Water-Soluble Propolis (Greit 120) and Human Interferon Alfa (HuIFN- $\alpha$ N3) against Influenza Viruses in Vitro

Table 7 Antiviral activities of 10\% EEP and HuIFN- $\alpha \mathrm{N3}$ in the ratios 1:1, 1:2 and 2:1 expressed as ID $\mathrm{In}_{50}$ in $\mu \mathrm{g} / \mathrm{mL}$.

\begin{tabular}{|c|c|c|c|c|c|c|c|c|c|c|}
\hline Viruses & $10 \%$ EEP & $\begin{array}{l}\mathrm{ID}_{50} \\
\text { inhibition }\end{array}$ & $\begin{array}{l}+ \text { HuIFN- } \\
\alpha \mathrm{N} 3(1: 1)\end{array}$ & $\begin{array}{l}\mathrm{ID}_{50} \\
\text { inhibition }\end{array}$ & $\begin{array}{l}+ \text { HuIFN- } \\
\alpha \mathrm{N} 3(1: 2)\end{array}$ & $\begin{array}{l}\mathrm{ID}_{50} \\
\text { inhibition }\end{array}$ & $\begin{array}{l}+ \text { HuIFN- } \\
\alpha \mathrm{N} 3(2: 1)\end{array}$ & $\begin{array}{l}\mathrm{ID}_{50} \\
\text { inhibition }\end{array}$ & Ribavirin & $\begin{array}{l}\mathrm{ID}_{50} \\
\text { inhibition }\end{array}$ \\
\hline Influenza A & $82 \pm 11$ & - & $35 \pm 7$ & 46.41 & $22 \pm 8$ & 59.31 & $42 \pm 4$ & 39.71 & $20 \pm 2$ & 61.91 \\
\hline$T$-test & & & 0.67 & & 0.87 & & 0.58 & & 0.97 & \\
\hline Influenza B & $62 \pm 6$ & - & $31 \pm 6$ & 31.00 & $15 \pm 6$ & 47.00 & $31 \pm 7$ & 30.90 & $28 \pm 2$ & 34.40 \\
\hline$T$-test & & & 0.51 & & 0.83 & & 0.49 & & 0.62 & \\
\hline
\end{tabular}

$\mathrm{ID}_{50}=$ Concentration of sample needed to reduce the virus-induced CPE to $50 \%$.

Table 8 Ribavirin $\mathrm{ID}_{50}$ index: Comparison of $\mathrm{ID}_{50}$ activity of $10 \%$ WSP (Greit 120) in combination with $\mathrm{HuIFN- \alpha N3}$ in ratios $1: 1,1: 2$ and $2: 1$ to ribavirin.

\begin{tabular}{lllll}
\hline Viruses & $10 \%$ WSP (Greit 120) & + HuIFN- $\alpha$ N3 $(1: 1)$ & + HuIFN- $\alpha$ N3 $(1: 2)$ & + HuIFN- $\alpha$ N3 $(2: 1)$ \\
\hline Influenza A & $1 \pm 0.05$ & $1 \pm 0.09$ & $0.6 \pm 0.04$ & $1 \pm 0.02$ \\
$T$-test & & -0.45 & -0.9 & 0.73 \\
Influenza B & $1 \pm 0.10$ & $1 \pm 0.03$ & $0.6 \pm 0.09$ & $1 \pm 0.06$ \\
$T$-test & & 0.76 & -0.83 & 0.39 \\
\hline
\end{tabular}

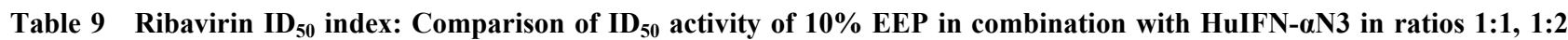
and $2: 1$ to ribavirin.

\begin{tabular}{lllll}
\hline Viruses & $10 \%$ EEP & + HuIFN- $\alpha$ N3 $(1: 1)$ & + HuIFN- $\alpha$ N3 $(1: 2)$ & + HuIFN- $\alpha$ N3 $(2: 1)$ \\
\hline Influenza A & $4 \pm 0.65$ & $1 \pm 0.76$ & $1 \pm 0.12$ & $2 \pm 0.9$ \\
$T$-test & & -0.08 & 0.9 & 0.94 \\
Influenza B & $2 \pm 0.22$ & $1 \pm 0.12$ & $0.5 \pm 0.05$ & $1 \pm 0.12$ \\
$T$-test & & 0.48 & -0.53 & 0.48 \\
\hline
\end{tabular}

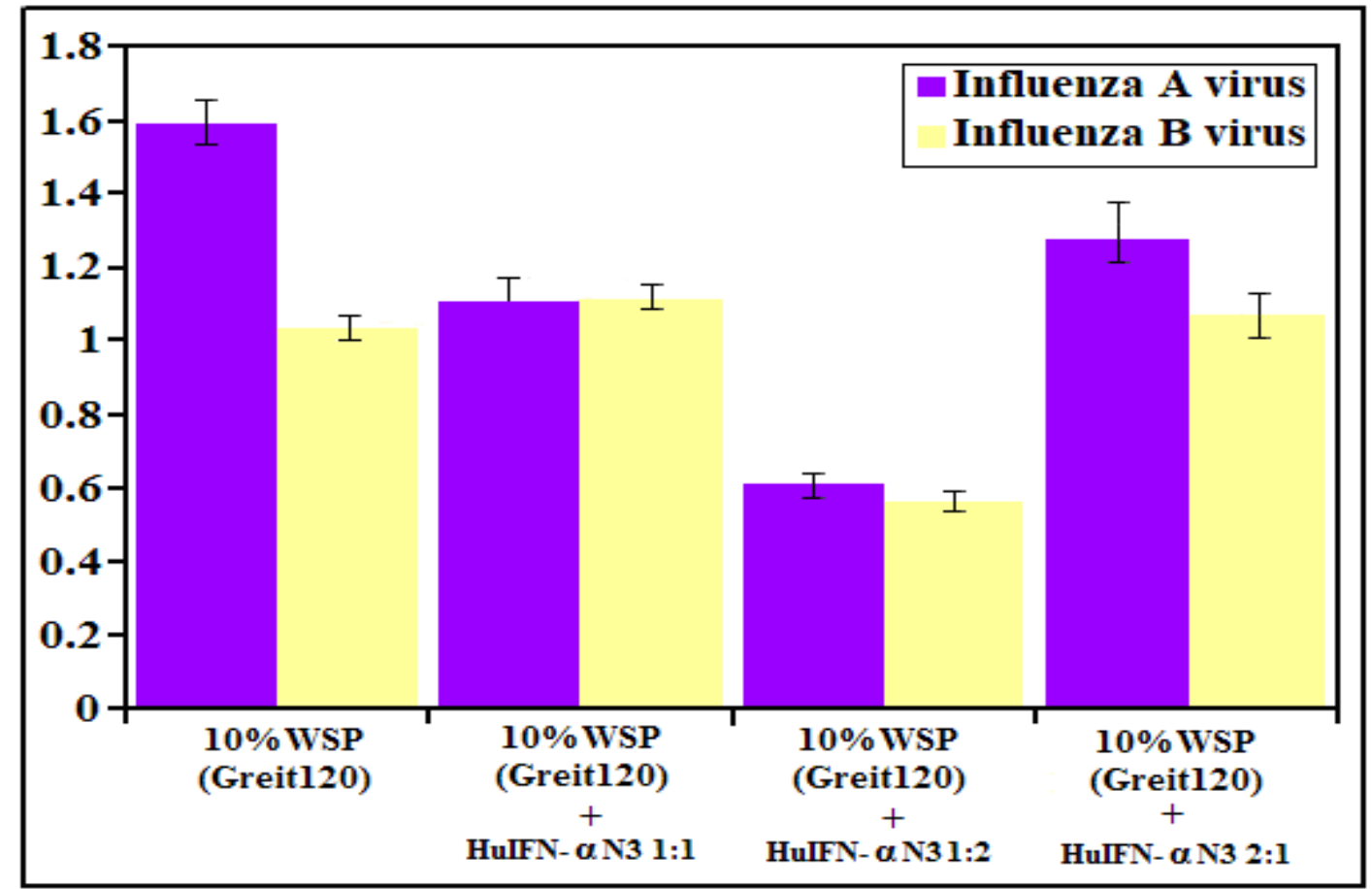

Fig. 4 Ribavirin ID $_{50}$ index of WSP (Greit 120) and/or combination with HuIFN- $\alpha$ N3 in ratios 1:1, 1:2 and 2:1. 


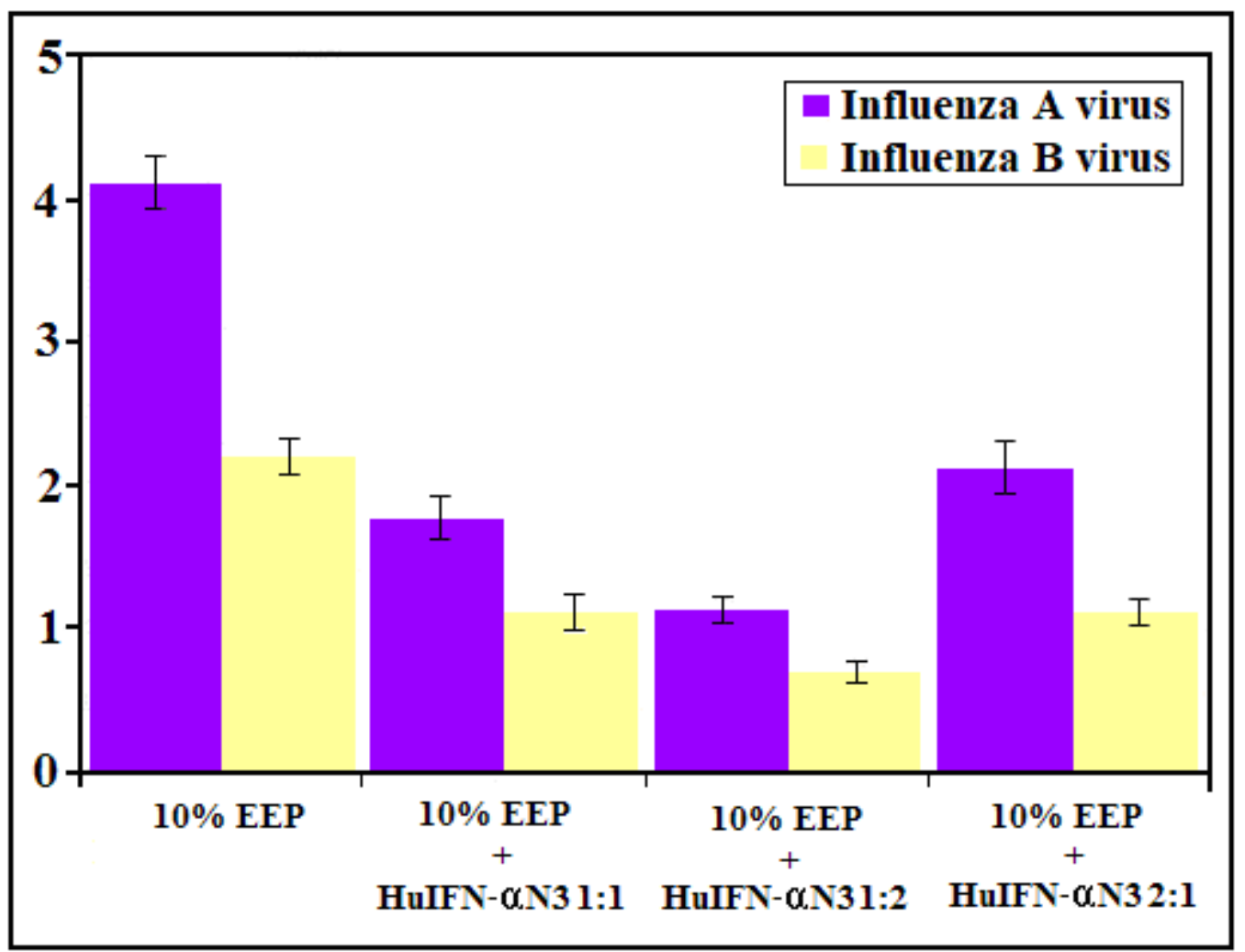

Fig. 5 Ribavirin ID $_{50}$ index of EEP and/or combination with HuIFN- $\alpha$ 3 in ratios 1:1, 1:2 and 2:1.

\section{Discussion}

The samples of very detailed analyzed WSP (Greit 120) (Table 4) containing different polyphenols: apigenin $\left(\mathrm{ID}_{50} 8.1 \pm 4.7 \mu \mathrm{g} / \mathrm{mL}\right)$, chrysin $\left(\mathrm{ID}_{50}>100\right.$ $\mu \mathrm{g} / \mathrm{mL}$ ), kaempferol ( $\left.\mathrm{ID}_{50} 24.8 \pm 4.3 \mu \mathrm{g} / \mathrm{mL}\right)$, quercetin $\left(\mathrm{ID}_{50}>100 \mu \mathrm{g} / \mathrm{mL}\right)$ and caffeic acid $\left(\mathrm{ID}_{50}\right.$ $49.7 \pm 5.0 \mu \mathrm{g} / \mathrm{mL}$ ) already showed anti-influenza activity in vitro [33]. The anti-influenza $\mathrm{A}$ and $\mathrm{B}$ virus activity of complete WSP (Greit 120) molecule is: $\mathrm{ID}_{50} 31 \pm 0.9 \mu \mathrm{g} / \mathrm{mL}$ for influenza A virus and ID $_{50} 29$ $\pm 0.2 \mu \mathrm{g} / \mathrm{mL}$ for influenza $\mathrm{B}$ virus, what is bit lower, but comparable with ribavirin, having $\mathrm{ID}_{50} 20 \pm 0.2$ $\mu \mathrm{g} / \mathrm{mL}$ for influenza $\mathrm{A}$ and $\mathrm{ID}_{50} 28 \pm 0.4 \mu \mathrm{g} / \mathrm{mL}$ for influenza $\mathrm{B}$. When HuIFN- $\alpha \mathrm{N} 3$ is added to Greit 120 in ratio $1: 1$, the $\mathrm{ID}_{50} 22 \pm 0.2 \mu \mathrm{g} / \mathrm{mL}$ for influenza $\mathrm{A}$ and $31 \pm 0.3 \mu \mathrm{g} / \mathrm{mL}$ for influenza $\mathrm{B}$ are found. When this ratio is $1: 2$, the $\mathrm{ID}_{50}$ is $12 \pm 0.2 \mu \mathrm{g} / \mathrm{mL}$ for influenza $A$ and $19 \pm 0.7 \mu \mathrm{g} / \mathrm{mL}$ for influenza $B$ virus. The ratio $2: 1$ shows the $\mathrm{ID}_{50} 25 \pm 0.6 \mu \mathrm{g} / \mathrm{mL}$ for influenza A and $30 \pm 0.2 \mu \mathrm{g} / \mathrm{mL}$ for influenza B. The highest increase was found when WSP (Greit 120) is combined with HuIFN- $\alpha \mathrm{N} 3$ in ratio 1:2. To elucidate out the mechanisms of anti-influenza activity of WSP (Greit 120) it was found that caffeic acid from it could restore the viability of cells infected with influenza virus in a dose dependent manner [34]. To find working mechanisms of this anti-influenza activity, it was measured the relative value of influenza virus RNA in cultured cells with and without antiviral compounds. It was found that the relative value of influenza virus RNA/viable cells was not significantly different between groups with different compound concentration. So it is possible that WSP (Greit 120) has no direct influence on an influenza virus or does not interact with influenza virus components, although $\mathrm{Li}$ et al. [35] reported that caffeoylquinic acid from WSP (Greit 120) binds to the gp120 of RSV (respiratory syncytial virus) and inhibits virus-cell fusion events in the early stage of the replication cycle. Thus, the anti-influenza activity of WSP (Greit 120) is not derived from an inhibition of virus replication, as 
is true for a neuraminidase inhibitory drug, but may be due to another mechanism, such as an enhancement of cell resistance. As to the effect on antiviral executor genes, WSP (Greit 120) enhanced myxovirus resistance 1 (Mx1) expression [36]. Different specificities in antiviral effects of HuIFN- $\alpha$ N3 against influenza $\mathrm{A}$ and $\mathrm{B}$ viruses were reported as in vitro and in vivo [37]. They share the same specific cell receptor, interferon type I receptor (IFN- $\alpha \mathrm{R}$ ) composed of two subunits, IFN- $\alpha \mathrm{R} 1$ and IFN- $\alpha \mathrm{R} 2$, and interact with its different regions [38]. Antiviral activity of HuIFN- $\alpha \mathrm{N} 3$ against influenza A, B and C viruses is mediated, at the least in part, by the induction of intracellular antiviral proteins, such as MxA protein. It is induced by HuIFN- $\alpha$ N3 as a whole and inhibits the replication of various influenza viruses $[39,40]$.

WSP (Greit 120) enhances the anti-influenza activity of HuIFN- $\alpha \mathrm{N} 3$ in dose-dependent ratio via enhanced resistance 1 (Mx1) expression and MxA induction of influenza virus replication inhibition.

\section{Conclusions}

From the performed experimental study, the following conclusions may be drawn. The anti-influenza A and B activity of WSP (Greit 120) is $\mathrm{ID}_{50} 31 \pm 0.9 \mu \mathrm{g} / \mathrm{mL}$ for influenza $\mathrm{A}$ virus and $\mathrm{ID}_{50} 29$ $\pm 0.2 \mu \mathrm{g} / \mathrm{mL}$ for influenza B. It is bit lower, but comparable with ribavirin, having $\operatorname{ID}_{50} 20 \pm 0.2$ $\mu \mathrm{g} / \mathrm{mL}$ for influenza $\mathrm{A}$ and $\mathrm{ID}_{50} 28 \pm 0.4 \mu \mathrm{g} / \mathrm{mL}$ for influenza B.

Combining WSP (Greit 120) with HuIFN- $\alpha \mathrm{N} 3$ in ratio 1:2 caused the highest increase of anti-influenza $\mathrm{A}$ and $\mathrm{B}$ viruses' activity in vitro.

Anti-influenza activity of the combination of WSP (Greit 120) with HuIFN- $\alpha \mathrm{N} 3$ is higher against influenza $\mathrm{B}$ than against influenza A virus.

This new formulation of WSP (Greit 120) and HuIFN- $\alpha$ N3 showing better anti-influenza activity, will definitely improve its application in flu infections.

\section{Acknowledgments}

The presented research was supported by Ivan Čermak, Crodux plini d.o.o., 10000 Zagreb, Croatia and in the frame of Croatian Institute for Experimental and Translation Oncology, in the Project "Oncolytic Newcastle disease virus in the veterinary medicine". Authors are indebted to Tomaž Velnar for English suggestions.

\section{Conflict of Interest}

The authors declared no potential conflicts of interest with respect to the research, authorship and/or publication of this article.

\section{References}

[1] Thompson, W. W., Shay, D. K., Weintraub, E., Brammer, L., Cox, N., Andreson, L. J., and Fukuda, K. 2003. "Mortality Associated with Influenza and Respiratory Syncytial Virus in the United States." JAMA 289 (2): 179-86.

[2] Dushoff, J., Plotkin, J. B., Viboud, C., Earn, D. J. D., and Simonsen, L. 2005. "Mortality due to Influenza in the United States-An Annualized Regression Approach Using Multiple-Cause Mortality Data." American Journal of Epidemiology 163 (2): 181-7.

[3] Cosmi, V. E., Ali, M. S., and Farid, L. 2013. "Bee Propolis as a New Modality for Treatment of H1N1 Influenza." Journal of American Science 9 (12): 261-4.

[4] Kai, H., Obuchi, M., Yoshida, H., Watanabe, W., Tsutsumi, S., Park, K. Y., Matsuno, K., Yasukawa, K., and Kurokawa, M. 2014. "In Vitro and in Vivo Anti-influenza Virus Activities of Flavonoidss and Related Compounds as Components of Brazilian Propolis (AF-08)." Journal of Functional Foods 8 (5): 214-23.

[5] England, A. J., Champlin, R. E., Wade, R. P., Kantarjian, H., Atmar, L. R., Tarrant, J., Yousuf, H., Regnery, H., Klimov, A. I., Cox, N. J., and Whimbey, E. 1998. "Common Emergence of Amantadine- and Rimantadine-Resistant Influenza A Viruses in Symptomatic Immunocompromised Adults." Clin. Infect. Dis. 26 (6): 1418-24.

[6] Banskota, A. H., Tezuka, Y., and Kadota, S., 2001. "Recent Progress in Pharmacological Research of Propolis." Phytother Res. 15 (7): 561-71.

[7] Marcucci, M. C. 1995. "Propolis: Chemical Composition, Biological Properties and Therapeutic Activity." Apidologie 26 (2): 83-99 
[8] El-Khawaga, O. A. Y., Salem, T. A., and Elshal, M. F. 2003. "Protective Role of Egyptian Egyptian Propolis against a Tumour in Mice." Clin. Chim. Acta. 338 (1-2): 11-6.

[9] Borrelli, F., Maffia, P., and Pinto, L. 2002. "Phytochemical Compounds Involved in the Anti-inflammatory Effect of Propolis Extract." Fitoterapia 73 (Suppl 1): S53-63.

[10] Kujumgiev, A., Svetkova, I., Serkedijeva, Y., Bankova, V., Christov, R., and Popov, S. 1999. "Antibacterial, Antifungal and Antiviral Activity of Propolis of Different Geographic Origin.” J. Ethnopharmacol 64 (3): 235-40.

[11] Filipič, B., and Likar, M. 1976. "Inhibitory Effect of Propolis and Royal Jelly on Some Viruses." Interferon Scientific Memoranda (ISM). April (4): Memo AS-7/1-2.

[12] Amoros, M., Sauvage, F., Girard, L., and Cormier, M. 1992. "In the in Vitro Antiviral Activity of Propolis." Apidologie 23 (3): 231-40.

[13] Ito, J., Chang, F. R., Wang, H. K., Park, Y. K., Ikegaki, M., Kilgore, N., and Lee, K. H. B. 2001. "Anti-AIDS agents. 48 (1) Anti-HIV Activity of Moronic Acid Derivatives and the New Umbelliferon-Related Triterpenoids Isolated from Brazilian Propolis." J. Nat Prod 64 (10): 1278-81.

[14] Ayse, Y., Duan, G. G., Duran, N., Jedi, K., Bolgul, S. B., Miralogu, M., and Luz, M. 2016. "Antiviral Activity of Hatay Propolis against Replication of Herpes Simplex Virus Type 1 and Type 2." Med. Sic. Monti. 22 (2): 422-30.

[15] Filipič, B., and Likar, M. 1978. "Effect of Propolis, Royal Jelly and Interferon on Herpes Simplex Virus." Interferon Scientific Memoranda (ISM). October (10): Memo I-A646/1-5.

[16] Shimizu, T., Hino, A., Tsutsumi, A., Park, Y. K., Watanabe, W., and Kurokawa, M. 2008. "Anti-influenza Virus Activity of Propolis in Vitro and Its Efficacy against Influenza Infection in Mice." Antivir Chem Chemother 19 (1): 7-13.

[17] Serkedijeva, J., and Manolova, N. 1992. "In Vitro and in Vivo Anti-influenza Virus Activities of Flavonoids and Related Compounds as Components of Brazilian Propolis (AF-08)." Journal of Natural Products 55 (3): 294-7.

[18] Punainen, S., Veripavel, U. R., Tőlő, H., and Parkkinen, J. 1999. Alpha interferon manufacturing process using immunoadsorption and virus removal filtration. Patent No. WO 99/64440.

[19] Testa, D., Liao, M. J., Katalin, F., Rashidbaigi, A., and DiPaola, M. 1997. Composition containing human alpha interferon species proteins and method for use it. US Patent No: 5,676,942.

[20] Antonelli, G. 2008. "Biological Basis for a Proper Clinical Application of Alpha Interferons." New
Microbiologica 31 (3): 305-18.

[21] Beilharz, M. W., Cummins, J. M., and Bennet, A. I. 2007. "Protection from Lethal Influenza Virus Challenge B Oral Type I Interferon." Biochem. Biophys. Res. Commun. 355 (3): 740-4.

[22] Kugel, D., Koch, G., Obojes, K., Roth, J., Kobinger, G. P., Kobasa, D., Haller, O., Staehli, P., and von Messling, V. 2009. "Intranasal Administration of Alpha Interferon Reduces Seasonal Influenza A Virus Morbidity in Ferrets." J. Virol. 83 (8): 3843-51.

[23] Filipič, B., Ciglar Grozdanić, I., Gottstein, Ž., Sindik-Milošević, T., Sladoljev, S., Mazija, H., Koren, S., and Šooš, E. 2007. "HuIFN- $\alpha$ N3 Affects the Replication of Avian Influenza $\left(\mathrm{H}_{5} \mathrm{~N}_{2}\right)$ Virus in the Embryonated Chicken Eggs." In Proceedings of Poultry Days VII, 223-9.

[24] Shi, S., Huang, K., Zhang, Y., Zhao, Y., and Du, Q. 2007. "Purification and Identification of Antiviral Components from Laggera Periodontal by High-Speed Countercurrent Chromatography.” Journal of Chromatography B 859 (1): 119-24.

[25] Prix, L., Maier, J., Jahn, G., and Hamprecht, K. 1998. “A Simplified Assay for Screening of Drug Resistance of Cell-Associated Cytomegalovirus Strains." Journal of Clinical Virology 11 (8): 29-37.

[26] Weiss, C. R., and Oostrom-Ram, T. 1989. "Inhibitory Effects of Ribavirin Alone or Combined with Human Alpha Interferon on Feline Infectious Peritonitis Virus Replication in Vitro." Veterinary Microbiology 20 (3): 255-65.

[27] Dai, J. X., You, C. H., Qi, Z. T., Wang, X. M., Sun, P. Q., Bi, W. S., Qian, Y., Ding, R. L., Du, P., and He, Y. 1987. "Childrens's Respiratory Viral Diseases Treated with Interferon Aerosol." Chin. Med. J. 100 (2): 162-6.

[28] Merigan, T. C., Reed, S. E., Hall, T. S., and Terrek, D. 1973. "Inhibition of Respiratory Virus Infection by Locally Applied Interferon." Lancet 1 (5): 563-7.

[29] Mishima, S., Yoshida, C., Akino, S., and Sakamoto, T. 2005. "Antihypertensive Effects of Brazilian Propolis: Identification of Caffeoylquinic Acids as Constituents Involved in the Hypotension in Spontaneously Hypertensive Rats." Biological and Pharmaceutical Bulletin 28 (10): 1909-14.

[30] Kumazawa, S., Tazawa, S., Noro, T., and Nakayama, T. 2000. "Analysis of Propolis by Liquid-Chromatography-Mass Spectrometry." Honeybee Science 21 (1): 164-8.

[31] Armstrong, J. A. 1981. "Cytophatic Effect Inhibition Assay for Interferon: Microculture Plate Assay." Methods Enzymol 78: 381-7.

[32] Urushisaki, T., Takemura, T., Tazawa, S., Fukuoka, M., Hosokawa-Muto, J., Araki, Y., and Kazuo Kuwata, K. 2011. "Caffeoylquinic Acids Are Major Constituents with 
Potent Anti-influenza Effects in Brazilian Green Propolis Water Extract." Evidence-Based Complementary and Alternative Medicine. Doi:10.1155/2011/254914.

[33] Kai, H., Obuchi, M., Yoshida, H., Watanabe, W., Tsutsumi, S., Kun-Park, Y., Matsuno, K., Yasukawa, K., and Kurokawa, M. 2014. "In Vitro and in Vivo Anti-influenza Virus Activities of Flavonoids and Related Compounds as Components of Brazilian Propolis (AF-08)." Journal of Functional Foods 8: 214-23.

[34] Kujumgijev, A., Svetkova, I., Serkedijeva, Y., Bankova, V., Christov, R., and Popov, S. 1999. "Antibacterial, Antifungal and Antiviral Activity of Propolis of Different Geographic Origin.” J. Ethnopharmacol 64 (2): 235-40.

[35] Li, Y., But, P. P. H., and Ooi, V. E. C. 2005. "Antiviral Activity and Mode of Action of Caffeoylquinic Acids from Schefflera heptaphylla (L.) Frodin." Antiviral Research 68 (1): 1-9.

[36] Hayakari, R., Matsumiya, T., Xing, F., Tayone, J. C., Dempoya, J., Tatsuta, T., Aizawa-Arashiro, T., Imaizumi, T., Yoshida, H., and Satoh, K. 2013. "Effects of Brazilian
Green Propolis on Double-Stranded RNA-Mediated Induction of Interferon-Inducible Gene and Inhibition of Recruitment of Polymorphonuclear Cells." J. Sci. Food Agric. 93 (3): 646-51.

[37] Schanen, C., Chieux, V., Pierre-Emmanuel Robert, P-E., Harvey, J., and Hober, D. 2006. "Correlation between the Anti-virus-induced Cytopathic Effect Activity of Interferon- $\alpha$ Subtypes and Induction of MxA Protein." In Vitro. Microbiol. Immunol. 50 (1): 19-24.

[38] Cook, J. R., Cleary, C. M., Mariano, T. M., Izotova, L., and Pestka, S. 1996. "Differential Responsiveness of a Splice Variant of the Human Type I Interferon Receptor to Interferons." J. Biol. Chem. 271 (6): 13448-53.

[39] Pavlovich, J., Zurcher, T., Haller, O., and Staeheli, P. 1990. "Resistance to Influenza Virus and Vesicular Stomatitis Virus Conferred by Expression of Human MxA Protein." J. Virol. 64 (7): 3370-5.

[40] Zurcher, T., Pavlovic, J., and Staeheli. P. 1992. "Mechanism of Human MxA Protein Action: Variants with Changed Antiviral Properties." EMBO J. 11 (9): 1657-61. 